Stockholm Studies in Child Law and Children's Rights

\title{
Corporal Punishment of Children
}

Comparative Legal and Social Developments towards Prohibition and Beyond

Edited by

Bernadette J. Saunders

Pernilla Leviner Bronwyn Naylor 


\title{
Stockholm Studies in Child Law and Children's Rights
}

\author{
General Editor \\ Pernilla Leviner (Stockholm University) \\ Editorial Board \\ Philip Alston (New York University) \\ Ursula Kilkelly (University College Cork) \\ Yanghee Lee (Sungkyunkwan University) \\ Marta Santos Pais (United Nations) \\ Kirsten Sandberg (University of Oslo)
}

Julia Sloth-Nielsen (University of the Western Cape and Leiden University)

VOLUME 4

The titles published in this series are listed at brill.com/sscl 


\section{Corporal Punishment of Children}

Comparative Legal and Social Developments towards Prohibition and Beyond

Edited by

Bernadette J. Saunders, Pernilla Leviner and Bronwyn Naylor

$$
\begin{aligned}
& \text { B R I L L } \\
& \text { NIJ H O F F } \\
& \text { LEIDEN | BOSTON }
\end{aligned}
$$


The Library of Congress Cataloging-in-Publication Data is available online at http://catalog.loc.gov LC record available at http://lccn.loc.gov/2018960502

Typeface for the Latin, Greek, and Cyrillic scripts: "Brill”. See and download: brill.com/brill-typeface.

ISSN 2405-8343

ISBN 978-90-04-35594-1 (hardback)

ISBN 978-90-04-35597-2 (e-book)

Copyright 2019 by Koninklijke Brill NV, Leiden, The Netherlands.

Koninklijke Brill NV incorporates the imprints Brill, Brill Hes \& De Graaf, Brill Nijhoff, Brill Rodopi, Brill Sense, Hotei Publishing, mentis Verlag, Verlag Ferdinand Schöningh and Wilhelm Fink Verlag. All rights reserved. No part of this publication may be reproduced, translated, stored in a retrieval system, or transmitted in any form or by any means, electronic, mechanical, photocopying, recording or otherwise, without prior written permission from the publisher.

Authorization to photocopy items for internal or personal use is granted by Koninklijke Brill NV provided that the appropriate fees are paid directly to The Copyright Clearance Center, 222 Rosewood Drive, Suite 910, Danvers, MA O1923, USA. Fees are subject to change.

This book is printed on acid-free paper and produced in a sustainable manner. 


\title{
Southern African Perspectives on Banning Corporal Punishment - a Comparison of Namibia, Botswana, South Africa and Zimbabwe
}

\author{
Julia Sloth-Nielsen
}

This chapter reviews recent judicial and legislative developments concerning steps towards - and against - the abolition of corporal punishment in four closely connected southern African jurisdictions: South Africa, Namibia, Botswana and Zimbabwe. Not only are these countries neighbours, they share a common legal heritage as recipients of a blend of Roman Dutch law and English law and, in the case of Namibia, the country was, until independence in 1990, a protectorate of South Africa with laws and institutions in common. Hence, all countries under discussion inherited from English law the "reasonable chastisement" defence available to parents utilising physical force against their children. In short, this meant that charges of assault could be countered with the common law defence that the parent was merely exercising legitimate parental authority. Although the scope of the application of the defence did narrow to exclude the most egregious forms of abuse in recent decades, in the face of mounting evidence of child abuse and changing social norms, it remained intact. This was the case even in the face of developing legislative measures to counter child abuse in various welfare and protection statutes in all of the four countries at defined points in the 2 oth century. ${ }^{1}$

The chapter dissects the legislative developments (in the case of Botswana and Namibia and South Africa), and judicial developments (Zimbabwe and South Africa) relating to corporal punishment, with the chief focus being corporal punishment in the home and corporal punishment as a judicial sanction for criminal offending. The legal position in South Africa has very recently taken centre stage via a judicial challenge to the constitutionality

1 For example, South Africa's Children Act of 196o and Child Care Act of 1983. The latter was also applicable until 2015 in Namibia, albeit that Namibia's Child Care and Protection Act 3 of 2015 has not been promulgated as the regulations have yet to be finalised at the time of writing. 
of the defence of reasonable chastisement, which unfolded as this chapter was being prepared. A discussion of the court's judgment and reasoning follows. Based on the diverse experiences of the countries discussed, the chapter concludes with observations about the most promising entry points for harmonisation of domestic law relating to corporal punishment with international law, and cautionary pointers as to approaches that should be avoided.

\section{Botswana}

Botswana enacted a new children's statute in 2009 (Child Welfare and Protection Act 8 of 2009). It is comprehensive, and covers both child protection and children in conflict with the law. A promising provision is to be found at section 27(4)(h), in Part IV of the Act dealing with parental duties and rights. This section enjoins parents to:

... respect the child's dignity and refrain from administering discipline which violates such dignity or adversely affects the physical, psychological or emotional well- being of a child or any other child living in the household.

However, this initial promise is limited by the clawback (or caveat) at section $27(5)$, which provides that subsection $27(4)(\mathrm{h})$ shall not be construed as 'prohibiting the corporal punishment of a child in such circumstances or manner as may be set out in this Act, the Penal Code or any other law.'

Section 61 (in the Part X dealing with 'Offences related to the care and protection of children'), continues in a similarly contradictory vein:

(1) No person shall subject a child to torture or other cruel, inhuman and degrading treatment or punishment.

(2) No person shall subject a child to correction which is unreasonable in kind or in degree relative to the age, physical and mental condition of the child, and which, if the child by reason of tender age or otherwise is incapable of understanding the purpose and fairness thereof.

(3) The provisions of this Act shall not be construed as prohibiting the corporal punishment of children in such circumstances or manner as may be set out in this Act or any other law.

(4) The Minister shall cause to be put in place parental guidance programmes aimed at developing the capacity of parents to discipline and guide their children appropriately. 
Section $85(\mathrm{~d})$ expressly provides for corporal punishment as a sentencing option for a child who has been convicted of an offence. Children are not singled out though, as corporal punishment remains a sentencing option for adults under the various penal statutes too.

Corporal punishment is also expressly permitted under the 1965 Constitution of Botswana ${ }^{2}$ and is permissible as a sanction in schools and in all alternative care settings (Global Initiative, 2018). The administration of corporal punishment in schools (and its use as a penal sanction) is circumscribed in considerable detail in ancillary legislation (how many strokes, on what part of the body they may be administered in respect of girls and boys, respectively, and so forth). It is worth noting that Botswana is one of the few countries that retains the death penalty and at least one execution was carried out in 2016 (Cornell Law School, 2011).

Macharia-Mokibi (2013) records that public attitudes at the time of the adoption of the Children's Act were conservative and 'difficult to shift', as an explanation as to why corporal punishment was retained as a sentence in the face of adverse United Nations Convention on the Rights of the Child (CRC) Committee Concluding Observations in 2004 (para. 36 and 37). UNICEF records that the intention of the Act was to harmonise Botswana's law with the (CRC), and in a situational analysis in 2010-11, UNICEF again noted (in strong terms) that the law should be amended to remove the explicit sanctioning of corporal punishment in its different guises (UNICEF, 2011, p.14).

UNICEF's Botswana's Annual Report for 2015 records that after 10 years, a further report to the CRC Committee had been prepared and that it would be submitted in 2016. No trace can be found on the official databases that this has occurred, however.

From available information and repute, the Parliament of Botswana is conservative $^{3}$ and this is bolstered by its relationship with Ntlo Ya Dikgosi. Established decades ago, but recently expanded and strengthened, it is an advisory council of non-elected traditional leaders. It is regularly consulted on parliamentary matters, and again wields a conservative influence.

In this milieu, law reform to prohibit corporal punishment in the home in the foreseeable future seems unlikely. The Government of Botswana has

2 The protection against cruel, inhuman and degrading treatment of punishment is subject to a disclaimer that it does not affect any law permitting corporal punishment as a sanction in force immediately before the coming into operation of the Constitution (Global Initiative, 2018, accessed 15 May 2017)

3 Only six of the 63 members of Parliament are women, also indicative of the extremely patriarchal nature of Batswana society. 
repeatedly rejected calls for its abolition, for example, at two successive Universal Periodic Review processes. It has only gone as far as to say that it will implement public awareness campaigns (Global Initiative, 2018).

It is not clear how the drafting of the clause of the Act outlawing unreasonable parental chastisement, or physical punishment, which is incomprehensible to the child by reasons of tender age (in section 61(2)), came about; certainly it would not have been supported by UNICEF who undoubtedly were key drivers behind the formulation of the revised statute. The similarity to the approach, that is, the attempt to narrow and define the defence of reasonable chastisement by the Canadian Supreme Court of Appeal in Canadian Foundation for Children, Youth and the Law $v$ Attorney General Canada (2004) is fairly striking, however, and it can be speculated that, the drafting was done in-house by government lawyers, acting on the instructions of the executive, and borrowing from the Canadian precedent.

The prospects of a judicial challenge seem also to be limited by the express constitutional reference to corporal punishment, as an exception to the constitutional prohibition against torture and cruel, inhuman and degrading treatment or punishment. Nor has criticism at the international level, for example, by the CRC Committee or in the Universal Periodic Review process, swayed government. Botswana has yet to submit a report to the African Committee of Experts on the Rights and Welfare of the Child (ACERWC) under the African Children's Charter. The regional process of consideration of a report on children's rights implementation via a structure of the African Union may provide the only window of opportunity for meaningful engagement on the issue when that occurs, as the ACERWC has consistently expressed its support for a ban on corporal punishment in all settings (see for instance ACERWC Concluding Observations Mozambique (2015)).

\section{$3 \quad$ Namibia}

Juvenile whipping as a sentence was declared unconstitutional shortly after Namibia's independence in 199o. In Ex Parte Attorney-General, Namibia: In Re Corporal Punishment by Organs of State 1991 (3) SA76 (NmSc), Acting Justice Mahomed declared that state sanctioned corporal punishment violated the constitutional prohibition on cruel, inhuman and degrading treatment or punishment. Although ground-breaking in the region, at that time, the judgment was limited to punishment sanctioned by the state. This included corporal punishment in state schools but seemingly did not apply to traditional courts which could impose it as a sanction, nor to alternative care settings, such as 
children's homes and foster care. The uncertainty about the reach of the decision (insofar as it applied to corporal punishment applied by the state) was raised again in 2016. A High Court ruling confirmed that the ban on corporal punishment in the Education Act applies in all Namibian schools, including private schools. Judge Elton Hoff stated that interpreting the laws prohibiting corporal punishment as applying only to teachers employed by the government would be 'an absurdity in that children enrolled at state schools would be protected against invasive punishment while those enrolled at private schools would not' (Van Zylv The State (CA 25-2014) [2016] NAHCMD 246 para. 164 (o5 September 2016)).

Namibia has recently passed the comprehensive and modernised Child Care and Protection Act 3 of 2015. It has not yet entered into force, though, as regulations to operationalise many sections have yet to be finalised. The Act was some years in the making ${ }^{4}$ and followed a highly consultative public process. Section 228, a dedicated section titled 'Corporal Punishment' in a chapter dealing with '[f] urther protective measures for children', provides as follows:

228. (1) A person who has control of a child, including a person who has parental responsibilities and rights in respect of the child, must respect the child's right to dignity conferred by Article 8 of the Namibian Constitution.

(2) Any legislative provision and any rule of common or customary law authorising corporal punishment of a child by a court, including the court of a traditional leader, is repealed to the extent that it authorises such punishment.

(3) A person may not administer corporal punishment to a child at any residential child care facility, place of care, shelter, early childhood development centre, a school, whether a state or private school or to a child in foster care, prison, police cell or any other form of alternative care resulting from a court order.

(4) The Minister must take all reasonable steps to ensure that -

(a) education and awareness-raising programmes concerning the effect of subsections (1), (2) and (3) are implemented in all the regions in Namibia; and

(b) programmes and materials promoting appropriate discipline at home and in other contexts where children are cared for are available in all the regions in Namibia.

4 The author was an international consultant to the Government of Namibia during the inception stages of the Act's development in 2009-2010. 
One may question the provenance of this uniquely worded statutory prescription. Writing at the commencement of the legislative drafting process in 2009, Kangandjela and Mapaure express the view that the first part of the formulation related to the interpretation of the decision of the Supreme Court of Namibia in Ex Parte Attorney General; in re corporal punishment by Organs of State in which corporal punishment imposed by organs of state - such as schools and as a sentence via the criminal justice system - was ruled unconstitutional as it infringed on the constitutional right to dignity insofar as it impaired the child's dignity and constituted degrading treatment (even if moderately applied and subject to strict controls). They opine that the Court in 1991 was mindful of the controversial societal implications of this decision, and did not express an opinion on corporal punishment in other settings, such as chastisement imposed by traditional authorities (or traditional courts) and in the home (Kangandjela and Mapaure, 2009, p.140).

Section 228(2) and (3) certainly serve to clarify some of the identified uncertainties, for example, relating to private schools and to corporal punishment imposed by traditional courts. It also applies to a person acting in loco parentis, such as care-givers and foster parents. But section 228(1) seeks only to affirm parents' and others' upholding of children's constitutional rights to dignity. As the provision stands, it could hardly have attracted societal objection, since that would entail admitting that children do not have the right to dignity. Nor could the legislation have been legitimately framed to limit children's constitutional right to dignity without risk: when is it limited? How? To what extent? Is the limitation proportional to the aims sought to be achieved?

But the section as it stands does not by any means achieve a prohibition on corporal punishment in the home: the defence of reasonable chastisement is arguably left intact. And there is no remedy for breaches of section 228(1) should parents or others acting in loco parentis fail to uphold children's rights to dignity in the administration of discipline and guidance. Hence, it is proposed that the section is practically devoid of meaning.

Section 228(2) turns the wheel half circle, and reinforces the conclusion that the reasonable chastisement defence has survived the law-making process. This section extends the prohibition affirmed by the Supreme Court in 1991 to all courts, including traditional courts, and, at the same time, repeals any rules (whether in common law or statute) which permit such corporal punishment by a court. Note, however, that the section applies only to corporal punishment imposed upon a child by a court - the abolition of the 'common law' provided for here does not explicitly cover corporal punishment administered by parents, who can still adduce the defence of reasonable chastisement. 
Section 228(3) appears to reinforce this point, as it extends the prohibition on corporal punishment to all settings where children may find themselves residential care, police cells, and so forth - except in the home. However, possibly borrowing from earlier proposals in neighbouring South Africa, the promotion of positive discipline, including in the home, is authorised by sections 228(4) and (5).

The initial draft of the bill that was debated at consultative workshops during the period 2009 - 2012 did not contain any provision related to corporal punishment in the home at all - possibly modelling the Children's Act in South Africa, adopted a couple of years earlier, where all references to corporal punishment were ultimately taken out - as discussed below. Yet this 'omission' clearly changed in the period between the drafting of the initial bill and the workshops and consultations undertaken upon it. ${ }^{5}$ It is likely that the UNICEF and/or other non-governmental actors ${ }^{6}$ were the drivers behind the articulation of a clause dealing expressly with corporal punishment. Moreover, the careful (yet meaningless) phrasing of section 228(1), coupled with the narrow prohibition that follows in section 228(2) (limiting the abolition of common law defences to court imposed corporal punishment) tends to suggest that avoiding dealing with corporal punishment in the home was a deliberate strategy, possibly to avoid difficult debates in Parliament about this contentious issue. It has been anecdotally ascertained that the clause, as drafted, elicited no debate at all in Parliament. Hence, the incremental advances contained in section 228, which although falling short of banning corporal punishment in the home do, in and of themselves, represent quite significant steps forward, sailed through unscathed.

Because the Act is of very recent provenance, further legislative reforms to address corporal punishment in the home more fully via parliamentary processes seem out of the question. An activist judiciary appears a more promising proposition: a truly purposive interpretation of section 228(1) could be read to exclude all forms of physical punishment as contrary to the dignity of the child, thereby outlawing parental physical chastisement. The Supreme Court of Namibia might well look to regional examples were it may be presented with an opportunity to explain what is meant by parents, or those having control of a child, 'respecting the child's constitutional right to dignity. ${ }^{7}$ Equally though, and weighing against such an interpretation being adopted in any court challenge to the limits of parental authority, is the fact that the legislature did have

5 The initial drafting was undertaken by a South Africa consultant.

6 Such as the Windhoek based Legal Assistance Centre (www.lac.org.na).

7 The wording of S 229(1). 
the opportunity to expressly deal with corporal punishment in the home, yet it did not seize the chance to do so. The well-known maxim of legislative interpretation often invoked in our courts, and those courts in the other countries discussed here, namely inclusio unius exclusio alterius (loosely translated as 'by referring expressly to the one, it appears that the other possibilities not mentioned are excluded'), militates against a purposive reading of section 228(1) to entail that it extinguished the defence of reasonable parental chastisement.

Namibia has (as have many sub-Saharan African countries) also enacted modern domestic violence legislation (Combating of Domestic Violence Act 4 of 2003). The definition of domestic violence contained therein is expansive. It includes physical abuse, which includes 'physical assault or any use of physical force against the complainant' (section 2(1)(a)). Notwithstanding any other law, section 4(5) permits a minor to apply for a protection order without the assistance of an adult person if the court is satisfied that the minor has sufficient understanding to make the proposed application. However, section $7(2)$ (b) does authorise a court to refuse to grant a protection order if minor or trivial acts or incidents of domestic violence are alleged. This could be used to resist an application for a protection order for parental corporal punishment, although it is not entirely clear. It remains an anachronism as to how domestic violence protection (in one sphere) interacts with child protection laws (in another). The same observation would have held true, until now, for South Africa as well.

\section{$4 \quad$ Zimbabwe}

In 2013, Zimbabwe adopted a new constitution, with a strong bent towards human rights. Children's rights are specifically protected by section 81 , though they are of course beneficiaries of all the rights contained in the parts of the constitution that can be termed the Bill of Rights.

Corporal punishment of children has also been the subject of constitutional litigation. The judgment in $S v C$ (a minor) came before the Harare High Court on review in December 2014. The accused had been convicted and sentenced to a moderate whipping of three strokes with a rattan cane, which was a lawful punishment for juvenile offenders under an exception to the prohibition on torture or cruel, inhuman or degrading treatment of punishment under the previous Zimbabwean constitution. ${ }^{8}$ But under the 2013 Constitution, the right

8 The question of whether the administering of corporal punishment is cruel, inhuman or degrading treatment came before the Supreme Court of Zimbabwe in 1990 in $S v$ A Juvenile 
to freedom from torture or cruel, inhuman or degrading treatment or punishment is provided for under section 53 (without exceptions), and section 86(3) (c) lists this right as one of those in respect of which 'no law may permit such torture or cruel, inhuman or degrading treatment or punishment to occur', and in respect of which 'no person may be permitted to violate it.' The Harare High Court viewed this as leading to the conclusion that corporal punishment as a sentence was now unconstitutional; a conclusion strengthened if regard is given to further provisions in the new constitution which protect the rights to personal security, equality and non-discrimination. The Court relied heavily on international instruments which had been ratified by Zimbabwe, including the key children's rights texts, with most detail accorded to the African Charter on the Rights and Welfare of the Child (1990). Section 2(1) of the 2013 Constitution states that 'the Constitution is the supreme law of Zimbabwe and any law, practice custom or conduct inconsistent with it is invalid to the extent of the inconsistency'. Under the circumstances therefore, whilst the Criminal Procedure and Evidence Act [Cap 9:07] (containing the sentencing provisions for child offenders) remained in force, the Court held that its section 353(1) is now an invalid law.

The Court continued to opine that although it was not an issue directly before the Court, it seemed that section 53 of the new constitution appeared to outlaw the infliction of corporal punishment on children by their parents, guardians or by persons in loco parentis. This is because, in the view of the Court, the right not to be tortured or subjected to cruel, inhuman or degrading treatment or punishment is an absolute right, as explained above. Declining to certify the sentence of a whipping to be in accordance with 'real and substantive justice' in view of its constitutional invalidity, the Court directed the Prosecutor-General to apply to the Constitutional Court to have the declaration of constitutional invalidity of juvenile whipping as a sentence confirmed. The remarks on the possible unconstitutionality of corporal punishment imposed by parents are only an expression of opinion, however, and do not constitute binding precedent.

In 2015, the High Court made the same remarks concerning the same subject matter in the case of $S v$ Mufema \& Ors. The Court declared that the caning of juvenile offenders with a rattan cane is inconsistent with the values and fundamental principles of the new constitution.

1990 (4) SA151 (ZS) 168. The sentence was struck down as an affront to the dignity of the child, and as cruel, inhuman and unusual punishment. Nevertheless, s 353(1) of the Criminal Procedure and Evidence Act (Cap 9:07) authorising corporal punishment for juvenile offenders remained on the statute book for a further 27 years! 
Most recently, in Pfungwa and Justice for Children Trust v Headmistress Belvedere Junior Primary School, Minister of Education, Sport and Culture and Minister for Justice Legal and Parliamentary Affairs, the applicants filed for a constitutional declaratory order based on sections $5^{1}$ and 53 of the Constitution, alleging directly that corporal punishment in schools and in the home was constitutionally impermissible. They claimed the right to bring an action locus standi) on the basis of section $85(1)$ (d) of the Constitution, the public interest ground, as a basis for the launch of proceedings. The application centred on a teacher employed by the first respondent's school, who had used a thick rubber pipe to assault the 7-year-old child because the child's mother had failed to sign her reading homework. The child suffered deep red bruises on her back, and was so traumatised that she refused to go to school the following day.

According to the Court, her plight came to the public domain via a "whatsapp group" on which her mother posted pictures of the injuries, resulting in other children revealing that they too had been assaulted. The mother sought corrective action, which the first respondent evidently undertook to instigate. The second applicant joined the proceedings as

a corporate body registered according to the laws of Zimbabwe, [with the] function, it said, ... to fight for the protection of children. Its main objective, according to it, was to ensure that international standards which protect children were realised and actualised in Zimbabwe. (Pfungwa, p.2)

The applicants averred that

no one, whether a school, a teacher or a parent at home should inflict corporal punishment on children. They submitted that corporal punishment was physical abuse of children. They averred that the punishment more often than not resulted in physical trauma or injury to children. They insisted that corporal punishment in school was dangerous in that it was administered indiscriminately without any measure or control over the teachers. (Pfungwa, p.2)

They supported their application by reference to the Constitution, domestic and regional case law, expert evidence and reliance on international treaties to which Zimbabwe is a party.

The Attorney General had applied to be admitted as a friend of the court, but filed only opposing heads of argument (summarising his position) without underlying affidavits. But, said the Court, his heads of argument 'stood on nothing', which was ultimately conceded by his representative when appearing 
in Court. In effect, the order sought was therefore essentially unopposed and the Court was in the event satisfied with the merits of the application. The declaratory order sought was therefore granted, and the matter remitted to the Constitutional Court for confirmation of the constitutional invalidity of corporal punishment in schools and by parents or those acting in loco parentis.

Confirmation by the Zimbabwean Court in both matters (corporal punishment in the penal and education system) is still awaited - the matter has been postponed without a final date being determined, due to the transition occasioned by the recent appointment of a new Chief Justice. But the above cases indicate an auspicious start to strategic litigation to vindicate children's constitutional rights in Zimbabwe, bolstered by international treaty law, by the intervention of children's rights NGO s as co-applicants, and by the evident willingness of the judiciary to take bold steps to advance children's rights.

Arguably, too, the nature of the remedy sought in the second case (Pfungwa) was an important factor. Seeking a formal declaration of unconstitutionality was arguably a less 'confrontational' route to pursue than (for instance) a delictual remedy (a claim for damages against the school) or the insistence on criminal sanctions for the teacher concerned (as was the case in the Van $Z y l$ case in Namibia where the appeal resulted from a criminal conviction of the teachers for assault).

At the time of completion of this chapter, final word from the Constitutional Court of Zimbabwe is still awaited.

\section{South Africa}

Initially this chapter was organised with the countries discussed in alphabetical order. However, given that there were developments in South Africa that unfolded during the course of writing, South Africa was moved to the final position, as it offered the most recent consideration of the issue of parental chastisement.

South Africa's Children's Act 38 of 2005 is silent on the issue of corporal punishment in the home. In the landmark ruling of the Constitutional Court in its nascent days in 1995, judicial corporal punishment as a sentence for juveniles was ruled to be a violation of the right to freedom and security of the person (in particular the right not to be subjected to cruel, inhuman or degrading treatment or punishment which forms part of that provision $)^{9}$ in $S v$ Williams

9 In what was section $11(2)$ of the then Interim Constitution of 1994, now contained in section 12 of the (final) Constitution of 1996. 
(1995), Justice Langa was firmly of the view that 'a culture of authority' that legitimates violence by the state was incompatible with the Interim Constitution (para. 52). In weighing the perceived benefits of juvenile whipping against the rights it infringed (the limitations analysis), Justice Langa observed that this kind of corporal punishment involves the intentional infliction of pain on a human being by another human being 'at the instigation of the state'. The judge also expressed concern that the degree of pain inflicted was arbitrary, depending on the discretion of the person doing the whipping, as the only direction by the Court was the number of strokes to be administered.

However, the issue was decided on the infringement of the constitutional right to dignity and the right to freedom and security of the person, rather than on children's rights grounds. Children's rights are dealt with in section 28 of the South African Constitution: aspects of section 28 are discussed below. The Court also declined to traverse the argument that the sentencing provisions violated the equality clause because they applied only to boys and not to girls. Once the Court had found a violation of the right to freedom and security of the person, the Court held it unnecessary to also consider whether children's rights (or other rights) were infringed. Although this could be regarded as a missed opportunity, the (very) early constitutional context of the judgment must be born in mind, as well as the regional context, as both Namibia and Zimbabwe had already spawned recent judgments outlawing judicial whipping.

A subsequent development shortly thereafter that bears relevance relates to corporal punishment as a sanction in schools. This was outlawed by legislation in the South African Schools Act of 1996. However, the ban was challenged in Christian Education South Africa v Minister for Education (2000). As Ann Skelton points out, importantly, the phrasing of the right to freedom and security of the person in the final Constitution included the right to be free from violence from public or private sources (which was not the case when $S v$ Williams was decided under the Interim Constitution in 1995) (Skelton, 2015, p.344).

The parent bodies of the umbrella group of 196 Christian schools claimed that the provision of the South African Schools Act which prohibited physical punishment in schools infringed their individual, parental and community rights to freely practise their religion, and to delegate their powers of correction (derived from biblical texts) to teachers acting in loco parentis. They claimed this right (of chastisement and delegation) only for boy children however. The parents' action was opposed by the Minister for Education, who argued that the prohibition was sound and that South Africans have suffered, and continue to suffer, a surfeit of violence. The Minister asserted that the state had an obligation to ensure that learners' constitutional rights are protected, and that 
education is conducted in a manner that upholds the spirit, content and values of the Bill of Rights. The Constitutional Court assumed, without deciding this, that the applicants' right to freely practice their religion was indeed limited by the statutory prohibition. But in the ensuing limitations analysis, the Constitutional Court found that the limitation on parents' rights to delegate their powers of reasonable chastisement to teachers (acting in loco parentis) was reasonable and justifiable, and the failure to provide an exemption for these parent bodies to accommodate their religious views was not unreasonable and unjustifiable. Therefore, there was no infringement of their right to freedom of religion as they claimed. The Court indicated that the state is under a constitutional duty to take steps to diminish the amount of public and private violence in society and to protect children from maltreatment, abuse or degradation (section $28(1)(d)$ of the Constitution).

The facts of Christian Education South Africa did not require the Constitutional Court to decide the question as to whether corporal punishment in the home was also an infringement of the right to be free from violence from a private source, but the Court did compare the detached and institutional environment of a school to the 'intimate and spontaneous environment of the home' (Skelton, 2015, p.350). Whether this served to endorse (albeit obliquely) reasonable physical punishment by parents in the home environment was not clear. Ann Skelton was of the view, however, that subsequent remarks of the Constitutional Court made in the context of a later case concerning a domestic violence injunction ( $S v$ Baloyi, 2002) were useful. In Baloyi, the Constitutional Court referred to the hidden and repetitive character of domestic violence which has a ripple effect throughout society and is frequently concealed. Skelton argued that this statement could be used to counter the evident distinction the Court drew earlier between the supposed blissful sanctity of the home, and institutional environments of schools and other places where comparative strangers are (were) authorised to chastise children (Skelton, 2015, p.349).

South Africa now also has a fairly recent new Children's Act 38 of 2005, in force from 1 April 2010. The South African Law Reform Commission (SALRC) that was tasked with reviewing the then Child Care Act of 1983 and bringing it in line with the CRC, debated how to tackle the question of corporal punishment in the home, and suggested that this should be done by removing the common law defence of reasonable chastisement that was available to parents (SALRC, 2000, pp.120-121). This was, in the view of the author (a member of the Project Committee tasked with developing the new Act) intentional: it was designed to minimise the likely attention that such a move would attract, in the hope of sweeping it through difficult public debates and parliamentary processes more or less unseen. 
Nevertheless, stronger provisions were contained in the bill tabled in Parliament some years later, allegedly at the behest of government (Skelton, 2015, p.346). Bill 19 of 2006 went way beyond the modest proposal of the SALRC and contained a ban on corporal punishment in the home. The original clause 139 read as follows:

Discipline of children

139. (1) A person who has care of a child, including a person who has parental responsibilities and rights in respect of the child, must respect, promote and protect the child's right to physical and psychological integrity as conferred by section 12(1)(c), (d) and (e) of the Constitution.

(2) No child may be subjected to corporal punishment or be punished in a cruel, inhuman or degrading way.

(3) The common law defence of reasonable chastisement available to persons referred to in subsection (1) in any court proceeding is hereby abolished.

(4) No person may administer corporal punishment to a child or subject a child to any form of cruel, inhuman or degrading punishment at a [any] child and youth care centre, partial care facility or shelter or drop-in centre.

(5) The Department must take all reasonable steps to ensure that-

(a) education and awareness-raising programmes concerning the effect of subsections (1), (2), (3) and (4) are implemented throughout the Republic; and

(b) programmes promoting appropriate discipline are available throughout the Republic.

(6) A parent, care-giver or any person holding parental responsibilities and rights in respect of a child who is reported for subjecting such child to inappropriate forms of punishment must be referred to an early intervention service as contemplated in section 144.

(7) Prosecution of a parent or person holding parental responsibilities and rights referred to in subsection (6) may be instituted if the punishment constitutes abuse of the child.

This version therefore sought to abolish the common law defence of reasonable chastisement; it even expressly referred to the possible prosecution of parents in certain circumstances. However, this extended provision was tantamount to raising a red flag to a bull: it became very controversial in Parliament, and had to be removed from the bill in its entirety - thereby also eliminating the possibility of removing the reasonable chastisement defence - to enable the remainder of the Children's Act 38 of 2005 to be passed. Later attempts to insert a similar provision in the Regulations to the Act, attracted equally 
adverse parliamentary attention, and again, had to be removed. Since then, the Department of Social Development, the custodian of the Children's Act, has on occasion signalled its intention to consider further legislative steps to deal with corporal punishment in the home, but the shape and form that these might take was never made entirely clear: these could have been the intention to merely remove the defence of reasonable chastisement, or be more far reaching as in the 2006 bill. In its reply to the CRC Committee's list of issues developed as a precursor to the consideration of the Republic of South Africa's periodic report in September 2016, the following answer was provided in response to a question about measures being taken to reduce the very high rate of violence experienced by children in South Africa:

Government is in the process of developing a Child Protection Policy. This policy will provide the legislative response framework for the protection of children against corporal punishment in the home, and it will be incorporated into the third amendment Children's Bill. (Government of the Republic of South Africa: Reply to the CRC Committee List of Issues, 2016, para. 28)

Nevertheless, the author remains sceptical that parliamentary abolition was ever a real prospect, given the history of Parliament's steadfast refusal in the past. But the point is now moot.

In June 2017, the constitutionality of parental chastisement came before the courts for the first time, in the case of $Y G \nu S$ (case no 263/2016). The case commenced as a criminal conviction for assault committed by the father of a 13 year old boy. The father was originally charged with assault with intent to do grievous bodily harm, a more serious charge, but was convicted of common assault which is a possible alternative verdict to the more serious charge. He appealed his conviction, citing the reasonable chastisement defence and his exercise of his right to freedom of religion (as an adherent of the Muslim faith). The criminal appeal court took the step of inviting amicus curiae (friends of the court) submissions on the constitutionality of the reasonable chastisement defence, and oral hearings took place in August 2017. This is permissible since the Constitutional Court has previously held that a court may of its own accord raise and decide a constitutional issue where it would be in the interests of justice to do so, and where compelling reasons for doing so exist. The friends of the court agreed that this was such a case, with the proviso that if the Court were to agree that the defence was unconstitutional, it should have prospective effect only, and not affect the appellant's rights retrospectively. 
Of some importance is the entry into the arena of the Minister for Social Development (the custodian of the Children's Act), who filed a brief (but did not appear for oral argument). The Minister argued that the CRC required the abolition of all forms of corporal punishment, however light; that the Committee had expressed concerns about the lack of measures to abolish corporal punishment in the home in its 2016 Concluding Observations to South Africa; that a draft National Child Care and Protection Policy had indeed been prepared under the auspices of the Department in which a ban on harmful and humiliating punishment including corporal punishment was advocated and in which positive parenting skills and positive discipline practices were promoted; and that the reasonable chastisement defence was consequently in violation of the constitutional protection of children from abuse, neglect, maltreatment and degradation (Founding affidavit in $Y G \nu S$ : Minister of Social Development, 2016). The introduction to Parliament of amending legislation in the form of a Children's Act Amendment Bill was, however, not referred to in the submission. This was possibly deliberate, as it might have led to the Court deferring its decision pending parliamentary results.

Why is this important? It indicates the sharp distinction between the legislature and the executive - in South Africa it has been abundantly clear since 2006 that the executive desires abolition, but earlier attempts to see this to fruition have been thwarted by the legislature. This is discussed again in the conclusion.

In the judgment handed down on 19th October 2017, the Gauteng High Court indeed found that the common law defence of reasonable chastisement was unconstitutional. Writing for the Court, Judge Keightley put the question succinctly:

Provided that the person who applies the moderate physical force in question is the parent, and the victim is his or her child who is being disciplined, conduct that would otherwise be an unlawful assault, if meted out by and to anyone else, is rendered lawful. Is this constitutional in our democratic era? (Para. 35)

A catalogue of constitutional rights were implicated: the right to human dignity, the right to equal protection under the law, the right to be free from all forms of violence from either public or private sources, the right not to be treated or punished in a cruel, inhuman or degrading way, the right of children to be protected from maltreatment, neglect, abuse or degradation, and the constitutional principle that a child's best interests are of paramount importance in every matter concerning such child. Countering this were certain constitutional 
rights of parents, including the right to freedom of religion, belief and opinion and the rights of cultural and religious communities. The Court held further that the context of the inquiry was the family, which is a critical component in weighing and balancing the rights that are directly implicated.

The Court referred to the previous jurisprudence of the Constitutional Court in $S v$ Williams, highlighting the Court's special concern for the vulnerability of children and the need for the State to protect them (para. 40). Christian Education South Africa v Minister of Education (2000) was cited in support of the constitutional duty upon the state to diminish the amount of public and private violence in society generally (para. 43). That court had also highlighted the need for children to be protected from the potentially injurious consequences of their parents' religious practices, as it is in their best interests (para. 43).

In support of her position, Judge Keightley referred extensively not only to the CRC, but also to the two relevant General Comments of the CRC Committee, namely General Comment No. 8 on the Right of the Child to Protection from Corporal Punishment and other Cruel or Degrading Forms of Punishment (2006), and General Comment No. 13 (2011) on Violence against Children. The recent concluding observations of both the CRC Committee and the African Committee of Experts on the Rights and Welfare of the Child, regarding South Africa calling for a ban on corporal punishment in the home, are referenced in some detail.

The court in $Y G$ cited the now famous dictum in Constitutional Court matters involving sentencing of primary care-givers of children in the context of a possible custodial sentence..$^{10}$ It agreed that the ratification of the CRC, the introduction of children's constitutional rights and domestic legislation in the form of the Children's Act 38 of 2005 , all pointed to a 'critical mindshift in the relationship between parents, children and the protection of the law' (para. 46). Children hold constitutional rights in their own respect, and no longer through parents (para. 61). By contrast, courts have in the past emphasised the parent-centred nature of the reasonable chastisement defence - that it related to the rights of parents. Flowing from this was the fact that once the defence

10 'Every child has his or her own dignity. If a child is to be constitutionally imagined as an individual with a distinctive personality, and not merely as a miniature adult waiting to reach full size, he or she cannot be treated as a mere extension of his or her parents, umbilically destined to sink or swim with them... and foundational to the enjoyment of the right to childhood is the promotion of the rights as far as possible to live in a secure and nurturing environment free from violence, fear, want and avoidable trauma.' $S v M 2008$ (3) SA 232 (CC). 
was raised, the onus shifted to the State to show that the legitimate bounds had been exceeded. The focus on parental power is inimical to an approach rooted in the rights of the child.

Moreover, the common law did not define what reasonable chastisement was, meaning that an element of arbitrariness to the infliction of punishment or discipline was inevitable (para. 68). Further, the constitutional protection extends to violence from any private source, which render the child liable to protection from the state when the violence is inflicted at home and by parents in the same way as the state obligation extends to violence coming from a non-parental source (para.69).

Focussing on the child's right to dignity - a foundational constitutional value the court in $Y G$ viewed the right to dignity as being implicated in two ways. First, insofar as conduct breaches a child's right to physical integrity, 'a measure of degradation or loss of dignity' must inevitably occur (para. 72). Second, in recognising the reasonable chastisement defence which, were the victim an adult would constitute an assault, the law accords the child less protection and treats him or her with a lesser level of concern. This is inherently degrading for children who are then treated as second class citizens (para. 72). The effect of the defence is then to subsume children's dignity under that of their parents (para. 73). The differential treatment of adults and children via the reasonable chastisement defence violated the constitutional maxim that everyone is entitled to equal protection of the law. This is not, the Court held, a rational differentiation which would justify a breach of a constitutional right.

Moving to a different ground of justification, the Court found that the existence of the defence obstructed prosecutors' ability to prosecute parents who assault their children, and that this renders an already vulnerable group even more vulnerable (para. 76). 'The defence creates an off limits zone for state involvement, which is not conducive to facilitation of a child-focussed justice and protection system for children' (para. 79).

Finding no reasons for permitting parents to lawfully assault their children whilst emphasising that the Court supported positive parental discipline - the Court held that the reasonable chastisement defence is no longer constitutionally justifiable. A prospective order to that effect was therefore made. ${ }^{11}$

11 Freedom of Religion South Africa (FORSA) who were admitted as a one of the friends of the court have filed a notice applying for leave to appeal to the Supreme Court of Appeal against the finding of constitutional invalidity. Their arguments include that the judgment erodes the rights of parents to decide for themselves how best to discipline their own children; that the judgement overrides the belief and conscience of parents who 
The examples of Namibia and Botswana seem to indicate that parliamentary steps to abolish corporal punishment in the home have not borne fruit, absent a court order which Parliament is required to implement, (as in the case of the abolition of corporal punishment as a judicial sanction). In South Africa, attempts by the executive arm of government to introduce a ban met with fierce resistance by parliamentarians, such that the inclusion of detailed provisions spelling out the content of such a ban (and mandating the promotion of positive parental discipline programmes) threatened to scupper the entire Children's Bill as it was debated in Parliament. In short, the executive cannot force the legislature to do its bidding.

The above discussion does not answer the question whether a more indirect approach to legislative abolition - short of outlawing the practice on pain of criminal sanction - might pass muster. The example in point is the potential provision removing the defence of reasonable chastisement, as originally proposed in the South Africa law reform process. However, in the view of the author, who had previously supported this indirect approach, the Namibian example discussed above detracts hugely from this possibility having the necessary impact and sending the right message. The Namibian provision adds nothing to the discussion about whether moderate correction imposed by parents - the "loving smack" - is an affront to the dignity of the child concerned. It leaves the matter unresolved, and sows confusion. Even worse, it could be read to mean that "reasonable" correction is allowed - only unreasonable actions, offensive to the child's dignity, are targeted. This is what Botswana, (emulating perhaps the Canadian outcome?) has sought to achieve in its provision in section 61(2) permitting corporal punishment which is reasonable relative to the 'age, physical and mental condition of the child, and which, if the child by reason of tender age or otherwise is incapable of understanding the purpose and fairness thereof'.

The most promising lessons, it would appear, are to be learned from the region's courts. They have a proud history of striking down laws permitting corporal punishment or, in the case of Zimbabwe most recently, declaring

believe that holy texts allow (if not instruct) them to use moderate chastisement as one of the methods for raising and disciplining their children; and that the judgment will have the effect of criminalising good and well-intentioned parents who love their children. (See https://www.timeslive.co.za/news/south-africa/2017-11-11-for-sa-appeals-spankingjudgment/ accessed 18 December 2017), 2017. The Appeal by Freedom of Religion South Africa has been set down for November 2018. 
the practice of corporal punishment unconstitutional. The courts in Namibia, South Africa and Zimbabwe have often relied on each other's decisions for support. This is a commendable approach to silence potential arguments (which do surface) that corporal punishment is culturally sanctioned by African culture. ${ }^{12}$ However, a precondition for judicial abolition is that the Constitution itself is not ambiguous about the protection it affords to children's dignity, and or right to be free from cruel, inhuman or degrading treatment or punishment. Constitutional protection of children's full right to bodily integrity is therefore a pre-requisite.

\section{References}

\section{Treaties, Reports and Miscellaneous Sources}

African Charter on the Rights and Welfare of the Child (1990).

African Committee of Experts on the Rights and Welfare of the Child. Concluding Observations: Mozambique (Mozambique, 2015).

Cornell Law School, Cornell Center on the Death Penalty Worldwide: Death Penalty Database, $2011<$ https://www.deathpenaltyworldwide.org/country-search-post. cfm? country=Botswana $>$.

Founding affidavit in $Y G v S$ : Minister of Social Development, 2016: copy on file with the author.

Global Initiative to End All Corporal Punishment of Children, Country Report for Botswana (Botswana, 2018) <www.endcorporalpunishment.org/progress/countryreports/botswana.html>.

Kangandjela, N., Mapaure, C., "Work in Progress: the Child Care and Protection Act in Namibia" in O. Ruppel (ed.), Child Law in Namibia (Windhoek: Konrad Adenauer Stifting, 2009).

Macharia- Mokibi, Sentencing of children in conflict with the law, $2013<\mathrm{https}$ ://www. unicef.org/botswana/Unicef_Thari_Ya_Bana_2013.pdf>.

Skelton, A., "Sv Williams: a springboard for further debate about corporal punishment", Acta Juridica Juta and Co: Cape Town 2015, 336-359.

South African Law Reform Commission (SALRC), Report on the Review of the Child Care Act (Government of the Republic of South Africa, 200o).

Government of the Republic of South Africa: Reply to the CRC Committee List of Issues (2016).

12 Indeed Judge Keightley heads off this line of attack at footnote 63 of her judgement, citing the many African countries which have abolished corporal punishment in full or which have committed to doing so. 
UN Committee on the Rights of the Child. Committee Concluding observations: Botswana: UN Doc CRC/C/15/Add.242 (Botswana: United Nations, 3 November 2004). UNICEF, "The situation analysis of children and their families in Botswana 2010 - 2011" (UNICEF Botswana Country Office: Gabarone, 2011).

UNICEF, UNICEF Botswana's Annual Report for 2015, <https://www.unicef.org/about/ annualreport/files/Botswana_2015_COAR.pdf >.

\section{Laws}

Botswana Child Care and Protection Act 8 of 2009

Constitution of Namibia, 1990

Constitution of Botswana, 1961

Constitution of South Africa, 1996

Constitution of Zimbabwe, 2013

Namibia Child Care and Protection Act 3 of 2015

Namibia Combating of Domestic Violence Act 4 of 2003

South Africa Children's Act 38 of 2005

Zimbabwe Criminal Procedure and Evidence Act (Cap 9:07)

\section{Cases}

Canadian Foundation for Children, Youth and the Law v Canada (Attorney General) $2004 \mathrm{SCC}_{4}$

Christian Education SA v Minister of Education 2000(4) SA 757 (CC)

Ex Parte Attorney-General, Namibia: In re Corporal Punishment by Organs of State 1991 (3) SA76 (NmSc)

Pfungwa and Justice for Children Trust v Headmistress Belvedere Junior Primary School, Minister of Education, Sport and Culture and Minister for Justice Legal and Parliamentary Affairs HC 6029/2016

Sv A Juvenile 1990 (4) SA 151 (ZS) 168

$S v$ Baloyi (Minister of Justice and Another intervening) 2002 (2) SA 425 (CC)

$S v C$ (a minor) $H H$ 718-2014

$S v M 2008(3) S A 232(C C)$

S v Mufema \& Ors HH 409-2015

$S v$ Williams 1995 (3) SA 632 CC

$Y G \nu S$ (case no 263/2016)

Van Zylv The State (CA 25-2014) [2016] NAHCMD 246 (o5 September 2016)) 